\title{
Infection Prevention Measures Used in Hematopoietic Stem Cell Transplantation: Evidences for Practice $^{1}$
}

\author{
Livia Maria Garbin² \\ Renata Cristina de Campos Pereira Silveira ${ }^{3}$ \\ Fernanda Titareli Merízio Martins Braga ${ }^{2}$ \\ Emilia Campos de Carvalho ${ }^{4}$
}

This integrative review aimed to identify and assess evidence available about the use of high-efficiency air filters, protective isolation and masks for infection prevention in patients submitted to hematopoietic stem cell transplantation during hospitalization. LILACS, PUBMED, CINAHL, EMBASE and the Cochrane Library were used to select the articles. Of the 1023 identified publications, 15 were sampled. The use of HEPA filters is recommended for patients submitted to allogeneic transplantation during the neutropenia period. The level of evidence of protective isolation is weak (VI) and the studies evaluated did not recommend its use. No studies with strong evidence (I and II) were evaluated that justify the use of masks, while Centers for Disease Control and Prevention recommendations should be followed regarding the use of special respirators by immunocompromised patients. The evidenced data can support decision making with a view to nursing care.

Descriptors: Hematopoietic Stem Cell Transplantation; Bone Marrow Transplantation; Infection; Air Filtration; Patient Isolation; Masks.

\footnotetext{
${ }^{1}$ Paper extracted from "Medidas utilizadas na prevenção de infecções em transplante de células-tronco hematopoéticas: evidências para a prática", presented to Escola de Enfermagem de Ribeirão Preto, Universidade de São Paulo, SP, Brazil.

2 RN, Escola de Enfermagem de Ribeirão Preto, Universidade de São Paulo, WHO Collaborating Centre for Nursing Research Development, SP, Brazil. E-mail: Livia: liviagarbin@usp.br, Fernanda: titareli@eerp.usp.br.

${ }^{3}$ RN, Ph.D. in Nursing. Professor, Escola de Enfermagem de Ribeirão Preto, Universidade de São Paulo, WHO Collaborating Centre for Nursing Research Development, SP, Brazil. E-mail: recris@eerp.usp.br.

${ }^{4}$ RN, Ph.D. in Nursing. Full Professor, Escola de Enfermagem de Ribeirão Preto, Universidade de São Paulo, WHO Collaborating Centre for Nursing Research Development, SP, Brazil. E-mail: ecdcava@usp.br.
}

Corresponding Author: Lívia Maria Garbin Universidade de São Paulo. Escola de Enfermagem de Ribeirão Preto Departamento de Enfermagem Geral e Especializada Av. Bandeirantes, 3900 Bairro: Monte Alegre CEP: 14040-902 Ribeirão Preto, SP, Brasil E-mail: liviagarbin@usp.br 


\title{
Medidas utilizadas na prevenção de infecções em transplante de células-tronco hematopoéticas: evidências para a prática
}

Esta revisão integrativa teve como objetivo identificar e avaliar as evidências disponíveis em relação ao uso de filtros de ar de alta eficiência, isolamento protetor e máscaras para a prevenção de infecção em pacientes submetidos ao transplante de células-tronco hematopoéticas, durante a internação. Para a seleção dos artigos foram utilizadas as bases de dados LILACS, PubMed, CINAHL, EMBASE e a Biblioteca Cochrane. Das 1023 publicações identificadas, 15 foram incluídas na amostra. O uso dos filtros HEPA é recomendado para pacientes submetidos ao transplante alogênico, durante o período de neutropenia. O nível das evidências do isolamento protetor é fraco (VI) e os estudos avaliados não recomendam o seu uso. Não foram avaliados estudos com evidências fortes (I e II) que justifiquem o uso de máscaras, sendo indicado que sejam seguidas as recomendações dos Centers for Disease Control and Prevention quanto ao uso de respiradores especiais pelos pacientes imunocomprometidos. Os dados evidenciados podem auxiliar na tomada de decisão para a assistência de enfermagem.

Descritores: Transplante de Células-Tronco Hematopoéticas; Transplante de Medula Óssea; Infecção; Filtração do Ar; Isolamento de Pacientes; Máscaras.

\section{Medidas utilizadas en la prevención de infecciones en trasplante de células tronco hematopoyéticas: evidencias para la práctica}

\begin{abstract}
Esta revisión integradora tuvo como objetivo identificar y evaluar las evidencias disponibles en relación al uso de filtros de aire de alta eficiencia, aislamiento protector y máscaras en la prevención de infección en pacientes sometidos al trasplante de células tronco hematopoyéticas durante la internación. Para la selección de los artículos fueron utilizadas las bases de datos LILACS, PUBMED, CINAHL, EMBASE y la Biblioteca Cochrane. De las 1023 publicaciones identificadas, 15 fueron incluidas en la muestra. El uso de los filtros HEPA es recomendado para pacientes sometidos al trasplante alogénico durante el período de neutropenia. El nivel de las evidencias del aislamiento protector es débil (VI) y los estudios evaluados no recomiendan su uso. No fueron evaluados estudios con evidencias fuertes (I y II) que justifiquen el uso de máscaras, siendo indicado que deben ser seguidas las recomendaciones de los Centers for Disease Control and Prevention en lo que se refiere al uso de respiradores especiales por los pacientes inmunocomprometidos. Los datos evidenciados pueden auxiliar en la toma de decisiones para la asistencia de enfermería.
\end{abstract}

Descriptores: Trasplante de Células Madre Hematopoyéticas; Trasplante de Médula Ósea; Infección; Filtración del Aire; Aislamiento de Pacientes; Máscaras.

\section{Introduction}

Today, hematopoietic stem-cell transplantation (HSCT) represents a treatment alternative for different types of illnesses ${ }^{(1)}$, including malign and non-malign blood diseases, immunodeficiencies, innate metabolic errors and solid tumors ${ }^{(2)}$. It is considered a risk procedure, due to possible complications, particularly possible adverse and transfusion reactions when the hematopoietic stem cells (HSC) are infused(3), liver, hemorrhage, kidney, lung, neurological, heart, infectious and gastrointestinal complications.

The occurrence of infections is mainly related to the immunosuppression the conditioning regimen causes and constitutes an important cause of morbidity and mortality in these patients(2). Any category of causal agent can cause infections in any transplantation type or phase. 
One of the most concerning phases is the neutropenia that precedes the $\mathrm{CTH}$ graft, during which infection prevention measures are fundamental for successful treatment.

While some of these measures are based on scientific knowledge and follow Centers for Disease Control and Prevention (CDC) guidelines, others are based on experiences and personal opinions and have been a source of disagreement. Also, despite the existence of CDC guidelines on prevention measures, some are used with little consensus, particularly the use of high efficiency particulate air filters (HEPA), masks and protective isolation.

The function of HEPA filters is to prevent fungal infections, which is one of the items in the protective environment the $\mathrm{CDC}$ recommend for patients submitted to allogeneic $\mathrm{HSCT}^{(4-5)}$. Although indicated for allogeneic HSCT, it is also used in autologous HSCT. On the opposite, due to their high cost and difficult maintenance, some centers have abolished their use, even for allogeneic HSCT.

Regarding protective isolation, this concept was introduced for the first time in 1970 and meant patients' confinement to a private room and use of sterilized gowns, masks and gloves for care delivery(6); since that time, great variations have been observed in the component items of this isolation.

As experience showed that protective isolation did not fulfill its proposed goals, as a majority of infections came from endogenous flora, the CDC extinguished the recommendation for its use in $1983^{(7)}$. Nevertheless, many centers continued using it, which aroused countless inquiries on the efficacy of this measure.

The use of masks for infection transmission prevention is another controversial point that has been used empirically in many situations.

In view of these divergences, the need was verified to survey information with a view to guiding professionals on the use of these measures. Nurses play a fundamental role in this context, as they are part of care delivery to patients and their relatives in all transplantation phases ${ }^{(1)}$.

In view of the above, Evidence Based Practice (EBP) was selected as the theoretical framework. In this problem-solving approach, research results are used for decision making in practice. It is developed through the production of literature review methods that permit seeking, assessing and summarizing available evidence on the research theme ${ }^{(8)}$. Thus, an integrative literature review was developed, which does not only present the current state of science, but also contributes to the development of theories and is applicable in practice ${ }^{(9)}$.

This study aimed to identify and assess available evidence in literature on the use of HEPA filters, protective isolation and masks by patients, health professionals and/or visitors for infection prevention in patients submitted to HSCT during hospitalization.

\section{Methods}

An integrative is considered the systematic analysis and synthesis of research on a target theme. Its scope can be broad or restricted and the analysis type is descriptive. The method aims to reduce uncertainties on performed practices and to facilitate the decision process on actions and interventions that can result in more effective and cost-efficient health care ${ }^{(10)}$.

To elaborate this review, six phases were performed: identification of the theme or question of the integrative review, sampling or literature search, study ranking, study assessment, result interpretation and presentation of the integrative review ${ }^{(9,11-13)}$.

The guiding question was elaborated based on the PICO strategy, which stands for patient, intervention, comparison and outcomes. This current proposal helps to elaborate the clinical question and identify the descriptors that will be used to locate the studies, so as to maximize the recovery of evidence from the databases and focus on the research scope ${ }^{(14)}$.

Thus, to construct the guiding question, $\mathrm{P}$ were the patients submitted to HSCT, I the use of HEPA filters, protective isolation and/or masks, $\mathrm{C}$ the comparison of these interventions with other possible interventions or not, and $O$ the occurrence of infection. The question was formulated as: What evidence is available on the use of HEPA filters, protective isolation and masks for infection prevention in patients submitted to HSCT?

To select the articles, LILACS, CINAHL, MEDLINE, EMBASE and the Cochrane Library were consulted, using different search strategies with controlled and uncontrolled descriptors. Controlled descriptors are terms from a structured and organized vocabulary, that is, a topical descriptor used to index papers in the databases ${ }^{(15)}$, while non-controlled means that the term is not part of the "topical descriptor" and represents the textual words and their synonyms identified based on the reading of primary texts. The following controlled descriptors were selected: bone marrow transplantation, hematopoietic stem-cell transplantation, infection, infection control, patient isolation, respiratory protection 
devices, masks, air, filtration and air filtration: non controlled descriptors were: protective isolation, HEPA filters, laminar air flow, surgical mask and N95 mask.

The inclusion criteria were as follows: papers discussing care related to protective isolation, use of HEPA filters and/or masks for infection prevention in patients submitted to HSCT during hospitalization; published in journals; in English, Spanish or Portuguese; in the last 20 years. The exclusion criteria were: studies that included different populations of neutropenic patients in which results are presented in a generalized way; and publications that do not fit into the evidence level classification used(16)

This classification covers seven evidence levels, with level I: evidence coming from systematic reviews or meta-analyses of relevant randomized controlled clinical trials (RCCT) or of clinical guidelines based on systematic reviews of RCCT; level II: evidence deriving from at least one well-designed RCCT; level III: evidence from well designed clinical essays without randomization; level IV: evidence from well designed case-control or cohort studies; level V: evidence from systematic review of qualitative and descriptive studies; level VI: evidence from one single descriptive or qualitative study; level VII: evidence from expert opinions and/or expert committee reports. As this classification is based on the study design and its ability to affirm cause and effect, levels I and II are considered strong evidence, III and IV moderate and V to VII weak ${ }^{(16)}$.

The titles and abstracts of 1023 identified studies were read, resulting in the pre-selection of 49. After reading the full papers, 34 were excluded for the following reasons: publications in German and Japanese $(n=2)$, results presented without distinction between HSCT patients and those submitted to other types of chemotherapy ( $n=3)$, studies related to air, environment and/or ventilation system control and surveillance $(n=$ 6 ), research focus on other interventions or results ( $n=$ 9), publications that did not fit into the adopted evidence level ranking (narrative literature review, abstract, letter to the editor and guideline, $n=13$ ), and impossibility to get access to the full version of the article $(n=1)$.

Thus, 15 studies were selected, seven of which located in PUBMED, two in EMBASE, five in both PUBMED and EMBASE, and one in these two databases and the Cochrane Library. To extract the data from the papers, an instrument was used which nurses have previously employed(17). The selected publications were classified according to the methodological design and evidence level(12) and data synthesis was presented descriptively according to the following theme categories: use of HEPA filter, use of protection isolation and use of masks.

\section{Results}

The publications were included in the theme categories, use of HEPA filter ( $n=10)$, use of protective isolation $(n=9)$ and use of masks $(n=2)$. The same study may have been included in more than one category.

As for the research institution, twelve (80\%) were conducted in hospitals, while the remainder (20\%) was not linked with any institution, with one meta-analysis, one survey and one expert opinion. Four studies (26.6\%) were published in Bone Marrow Transplantation, five (33.3\%) in journals related to HSCT, hematology and/ or oncology: and three (20\%) papers were published in journals on infection; most papers came from England (46.6\%) and the United States of America (40\%).

As for the research design and evidence level(16), one study was classified as evidence level I (systematic review and meta-analysis), one as level IV (cohort study), one level $\mathrm{V}$ (systematic review of descriptive studies), eleven level VI (descriptive studies), and one level VII (expert opinion).

Figure 1 displays the synthesis of papers included in this integrative review ${ }^{(18-32)}$. Five studies were included which involved different neutropenic patient populations ${ }^{(19-21,24,26)}$, as results on HSCT receptors were presented independently.

\begin{tabular}{|c|c|c|c|c|c|}
\hline Study & Category & $\begin{array}{l}\text { Design/ } \\
\text { Sample }\end{array}$ & $\begin{array}{c}\text { Aim/ } \\
\text { Intervention }\end{array}$ & Main results & $\begin{array}{c}\text { Conclusion/ } \\
\text { Recommendation }\end{array}$ \\
\hline $\begin{array}{l}\text { Barnes, } \\
\text { Rogers }^{(18)}\end{array}$ & HEPA filter & $\begin{array}{l}\text { Descriptive } \\
38 \text { children } \\
\text { submitted to } \\
\text { allogeneic HSCT. }\end{array}$ & $\begin{array}{l}\text { Check the incidence of invasive } \\
\text { pulmonary aspergillosis before } \\
\text { and after the installation of } \\
\text { the HEPA filter at an HSCT } \\
\text { unit. Buildings were being } \\
\text { constructed nearby during } \\
\text { the study period. Half of the } \\
\text { children transplanted before } \\
\text { and half after the opening of the } \\
\text { filter unit. }\end{array}$ & $\begin{array}{l}32 \% \text { of children transplanted } \\
\text { before the opening of the } \\
\text { unit equipped with a filter } \\
\text { died of invasive pulmonary } \\
\text { aspergillosis. After the new } \\
\text { unit opened, no further } \\
\text { cases of aspergillosis were } \\
\text { identified. }\end{array}$ & $\begin{array}{l}\text { The HEPA filter can } \\
\text { offer protection against } \\
\text { airborne fungal infections. }\end{array}$ \\
\hline
\end{tabular}


(continuation)

\begin{tabular}{|c|c|c|c|c|c|}
\hline Study & Category & $\begin{array}{l}\text { Design/ } \\
\text { Sample }\end{array}$ & $\begin{array}{c}\text { Aim/ } \\
\text { Intervention }\end{array}$ & Main results & $\begin{array}{c}\text { Conclusion/ } \\
\text { Recommendation }\end{array}$ \\
\hline $\begin{array}{l}\text { Johnson et } \\
\text { al. }^{(19)}\end{array}$ & HEPA filter & Expert opinion & $\begin{array}{l}\text { To present European } \\
\text { professionals' } \\
\text { recommendations on fungal } \\
\text { infection prevention in } \\
\text { immunocompromised patients. }\end{array}$ & $\begin{array}{l}\text { A general recommendation } \\
\text { is the HEPA filter in } \\
\text { allogeneic HSCT, although } \\
\text { environmental and/or patient } \\
\text { surveillance is needed even } \\
\text { in rooms with a HEPA filter. }\end{array}$ & $\begin{array}{l}\text { The HEPA filter is } \\
\text { recommended in } \\
\text { allogeneic HSCT. In } \\
\text { autologous HSCT, the risk } \\
\text { of infection needs to be } \\
\text { verified before indicating } \\
\text { its use. }\end{array}$ \\
\hline Oren et al. ${ }^{(20)}$ & HEPA filter & $\begin{array}{l}\text { Descriptive } \\
\text { 1st phase: } 12 \\
\text { patients with } \\
\text { acute leukemia } \\
\text { 2nd phase: } 28 \\
\text { patients with } \\
\text { acute leukemia } \\
\text { 3rd phase: } 26 \\
\text { patients with } \\
\text { acute leukemia, } \\
\text { 168 submitted to } \\
\text { autologous and } \\
26 \text { to allogeneic } \\
\text { HSCT. }\end{array}$ & $\begin{array}{l}\text { Check the incidence of invasive } \\
\text { pulmonary aspergillosis. The } \\
\text { study was developed in three } \\
\text { phases. In the first, patients } \\
\text { did not receive antifungal } \\
\text { prophylaxis; in the second, } \\
\text { prophylaxis was started with } \\
\text { amphotericin B and, in the } \\
\text { third, besides amphotericin B, } \\
\text { the HEPA filter was installed } \\
\text { at the unit. During the study, } \\
\text { constructions and reforms } \\
\text { happened at the hospital. }\end{array}$ & $\begin{array}{l}\text { In the first and second } \\
\text { phases, aspergillosis } \\
\text { incidence levels were } 50 \% \\
\text { and } 43 \% \text {, respectively. This } \\
\text { infection was not diagnosed } \\
\text { in the third phase at the } \\
\text { new unit. However, } 29 \% \text { of } \\
\text { leukemia patients treated } \\
\text { at conventional units in the } \\
\text { same period developed } \\
\text { aspergillosis. Spore counts } \\
\text { in room air were significantly } \\
\text { higher in the first and second } \\
\text { phases. }\end{array}$ & $\begin{array}{l}\text { The non occurrence of } \\
\text { fungal infections can be } \\
\text { attributed to the use of } \\
\text { filters and is not related } \\
\text { with amphotericin B } \\
\text { prophylaxis. }\end{array}$ \\
\hline $\begin{array}{l}\text { Hahn et } \\
\text { al. }^{(21)}\end{array}$ & HEPA filter & $\begin{array}{l}\text { Cohort study } \\
91 \text { adult patients } \\
\text { submitted } \\
\text { to HSCT or } \\
\text { treatment } \\
\text { for onco- } \\
\text { hematological } \\
\text { diseases. }\end{array}$ & $\begin{array}{l}\text { To investigate the cause of an } \\
\text { A. flavus infection episode at a } \\
\text { unit divided in hematology and } \\
\text { HSCT wards. The HSCT wards } \\
\text { were equipped with a HEPA } \\
\text { filter, but the nursing station } \\
\text { was shared by both units and } \\
\text { did not have a filter. }\end{array}$ & $\begin{array}{l}\text { In the first semester of the } \\
\text { study year, no cases of } \\
\text { aspergillosis were identified. } \\
\text { In the second semester, } \\
10 \text { patients (18\%) were } \\
\text { diagnosed with infection } \\
\text { (one submitted to HSCT). } \\
\text { Conidiospore counts in } \\
\text { the air were higher at the } \\
\text { hematology unit, with a } \\
\text { mildewed wall close to } \\
\text { the nursing station as the } \\
\text { apparent source. }\end{array}$ & $\begin{array}{l}\text { According to the authors, } \\
\text { the HEPA filter prevented } \\
\text { cases of aspergillosis. } \\
\text { Its use is recommended } \\
\text { for patients with malign } \\
\text { hematological diseases. }\end{array}$ \\
\hline \multirow{2}{*}{$\begin{array}{l}\text { Krüger et } \\
\text { al. }^{(22)}\end{array}$} & HEPA filter & Descriptive & & & \\
\hline & & $\begin{array}{l}232 \text { patients } \\
\text { submitted to } \\
\text { autologous and } \\
448 \text { to allogeneic } \\
\text { HSCT. }\end{array}$ & $\begin{array}{l}\text { Check the incidence of } \\
\text { aspergillosis and monitor the air } \\
\text { at an HSCT unit. A construction } \\
\text { area was present near the } \\
\text { unit. The wards possessed a } \\
\text { HEPA filter, an anteroom with } \\
\text { double doors and positive } \\
\text { pressure. The unit door close } \\
\text { to the construction area was } \\
\text { sealed with adhesive tape, and } \\
\text { the entry changed to another } \\
\text { location. }\end{array}$ & $\begin{array}{l}\text { During the entire study, air } \\
\text { contamination was greater in } \\
\text { corridors and the construction } \\
\text { area than in the wards. } \\
\text { During the construction, } \\
\text { the spore load in the air } \\
\text { was higher in the corridor } \\
\text { than in the wards. After the } \\
\text { construction, the external } \\
\text { area became part of the } \\
\text { ward corridor, without any } \\
\text { difference in spore counts } \\
\text { inside the rooms. Incidence } \\
\text { levels of aspergillosis were } \\
\text { similar to other periods } \\
\text { (3.6\%). }\end{array}$ & $\begin{array}{l}\text { Fungal spore counts } \\
\text { in rooms with a HEPA } \\
\text { filter, double doors and } \\
\text { positive pressure were } \\
\text { lower in comparison with } \\
\text { environments without a } \\
\text { filter. }\end{array}$ \\
\hline $\begin{array}{l}\text { Nihtinen et } \\
\text { al. }^{(23)}\end{array}$ & HEPA filter & $\begin{array}{l}\text { Descriptive } \\
\text { 07 patients } \\
\text { submitted to } \\
\text { autologous, } 15 \\
\text { to allogeneic } \\
\text { HSCT and } 33 \\
\text { rehospitalizations } \\
\text { of previously } \\
\text { transplanted } \\
\text { patients. }\end{array}$ & $\begin{array}{l}\text { Check the incidence of } \\
\text { aspergillosis at an HSCT } \\
\text { ward equipped with a HEPA } \\
\text { filter, sealed windows and } \\
\text { double doors during a nearby } \\
\text { construction. A barrier was } \\
\text { constructed around the } \\
\text { construction area and a } \\
\text { surveillance scheme was } \\
\text { proposed. }\end{array}$ & $\begin{array}{l}\text { Particle and spore counts } \\
\text { in the air were significantly } \\
\text { higher in the external area } \\
\text { than inside rooms. The } \\
\text { samples of nasal cavity } \\
\text { material were negative. } 31 \% \\
\text { of oral cavity samples tested } \\
\text { positively for C. albicans. No } \\
\text { cases of aspergillosis were } \\
\text { diagnosed. }\end{array}$ & $\begin{array}{l}\text { The use of a HEPA filter } \\
\text { can reduce the incidence } \\
\text { of aspergillosis and } \\
\text { contamination originating } \\
\text { in construction dust. }\end{array}$ \\
\hline
\end{tabular}


(continuation)

\begin{tabular}{|c|c|c|c|c|c|}
\hline Study & Category & $\begin{array}{l}\text { Design/ } \\
\text { Sample }\end{array}$ & $\begin{array}{c}\text { Aim/ } \\
\text { Intervention }\end{array}$ & Main results & $\begin{array}{c}\text { Conclusion/ } \\
\text { Recommendation }\end{array}$ \\
\hline \multirow[t]{2}{*}{$\begin{array}{l}\text { Passweg et } \\
\text { al. }{ }^{(24)}\end{array}$} & HEPA filter & Descriptive & $\begin{array}{l}\text { Check whether the use of } \\
\text { the HEPA filter influences } \\
\text { transplantation results. IBMTR } \\
\text { data were used and patients } \\
\text { were included in the groups that } \\
\text { used a HEPA filter ( } \mathrm{n}=4238 \text { ) or } \\
\text { conventional protective isolation } \\
\text { (individual rooms with any } \\
\text { combination of measures like } \\
\text { hand washing, gloves, masks } \\
\text { and gowns, } n=827 \text { ). }\end{array}$ & $\begin{array}{l}\text { HSCT with HLA identical } \\
\text { donors: no difference in } \\
\text { fungal pneumonia cases } \\
\text { occurred between both } \\
\text { groups. HSCT with alternative } \\
\text { donors: greater probability } \\
\text { of fungal pneumonia among } \\
\text { transplanted patients < } \\
25 \text { years in conventional } \\
\text { isolation. This difference was } \\
\text { not significant in the group > } \\
25 \text { years. }\end{array}$ & $\begin{array}{l}\text { The use of a HEPA filter } \\
\text { seemed to decrease } \\
\text { transplantation-related } \\
\text { mortality and increase } \\
\text { survival after allogeneic } \\
\text { transplantation. This } \\
\text { benefit was more } \\
\text { evident among patients } \\
\text { with donors with HLA } \\
\text { disparities. }\end{array}$ \\
\hline & $\begin{array}{l}\text { Protective } \\
\text { isolation }\end{array}$ & $\begin{array}{l}5065 \text { patients } \\
\text { submitted to } \\
\text { allogeneic HSCT } \\
\text { for leukemia. }\end{array}$ & & $\begin{array}{l}\text { The probability of survival } \\
\text { was greater in groups treated } \\
\text { in rooms with a HEPA filter } \\
\text { than in conventional isolation. }\end{array}$ & \\
\hline $\begin{array}{l}\text { Krüger et } \\
\text { al.(25) }\end{array}$ & $\begin{array}{l}\text { HEPA filter } \\
\text { Protective } \\
\text { isolation } \\
\text { Masks }\end{array}$ & $\begin{array}{l}\text { Descriptive } \\
\begin{array}{l}180 \text { HSCT } \\
\text { centers registered } \\
\text { in the European } \\
\text { BMT Group. }\end{array}\end{array}$ & $\begin{array}{l}\text { Assess the situation } \\
\text { of strategies against } \\
\text { infection used in European } \\
\text { transplantation centers through } \\
\text { a survey. }\end{array}$ & $\begin{array}{l}\text { Autologous HSCT: HEPA filter } \\
\text { used in } 47.2 \% \text { and reverse } \\
\text { isolation in } 63.6 \% \text { of centers. } \\
\text { Facial masks were used by } \\
65.1 \% \text { of professionals and } \\
60.8 \% \text { of visitors. Allogeneic } \\
\text { HSCT: } 60.6 \% \text { of centers } \\
\text { used a HEPA filter and } 78 \% \\
\text { reverse isolation. } 74.2 \% \text { of } \\
\text { professionals and } 63.6 \% \text { of } \\
\text { visitors used facial masks. }\end{array}$ & $\begin{array}{l}\text { The strategies used } \\
\text { in allogeneic HSCT } \\
\text { are explained by high } \\
\text { morbidity and mortality } \\
\text { related to infection; } \\
\text { strategies used in } \\
\text { autologous HSCT do } \\
\text { not reflect treatment } \\
\text { development and differ } \\
\text { from current guidelines. }\end{array}$ \\
\hline \multirow[t]{2}{*}{$\begin{array}{l}\text { Schlesinger } \\
\text { et al. }{ }^{(26)}\end{array}$} & HEPA filter & $\begin{array}{l}\text { Systematic review } \\
\text { and meta-analysis }\end{array}$ & $\begin{array}{l}\text { Perform a systematic review } \\
\text { and meta-analysis of studies } \\
\text { that assessed infection control } \\
\text { measures for cancer patients } \\
\text { submitted to chemotherapy. } \\
\text { The two main interventions } \\
\text { analyzed were protective } \\
\text { isolation (including air filter use } \\
\text { combined with endogenous } \\
\text { flora barrier or suppression } \\
\text { measures in this case) and } \\
\text { outpatient care. }\end{array}$ & $\begin{array}{l}\text { In the allogeneic HSCT } \\
\text { group }(n=5931) \text { and in the } \\
\text { autologous HSCT or acute } \\
\text { leukemia group }(n=916), \\
\text { a significant decrease in } \\
\text { mortality and infections was } \\
\text { verified. }\end{array}$ & $\begin{array}{l}\text { The HEPA filter should } \\
\text { be reserved for high-risk } \\
\text { patients and for places } \\
\text { where episodes occurred. } \\
\text { Antibiotics mediated } \\
\text { the beneficial effects of } \\
\text { protective isolation. The } \\
\text { use of barrier measures } \\
\text { can reduce the incidence } \\
\text { of cross-infection. }\end{array}$ \\
\hline & $\begin{array}{l}\text { Protective } \\
\text { isolation }\end{array}$ & $\begin{array}{l}40 \text { prospective } \\
\text { studies that } \\
\text { addressed } \\
\text { care delivery to } \\
\text { autologous or } \\
\text { allogeneic HSCT } \\
\text { patients, or to } \\
\text { chemotherapy } \\
\text { patients due to } \\
\text { hematological } \\
\text { diseases or solid } \\
\text { tumors. }\end{array}$ & & $\begin{array}{l}\text { Barrier isolation significantly } \\
\text { contributed to reduce } \\
\text { candidiasis and gram-positive } \\
\text { infections. The use of isolated } \\
\text { antibiotics showed to reduce } \\
\text { all mortality causes. }\end{array}$ & \\
\hline $\begin{array}{l}\text { Kumar et } \\
\text { al. }{ }^{(27)}\end{array}$ & $\begin{array}{l}\text { HEPA filter } \\
\text { Protective } \\
\text { isolation }\end{array}$ & $\begin{array}{l}\text { Descriptive } \\
40 \text { patients } \\
\text { submitted to } \\
\text { allogeneic HSCT }\end{array}$ & $\begin{array}{l}\text { Present the experience of } \\
\text { allogeneic HSCT patients in } \\
\text { individual rooms without a } \\
\text { HEPA filter. Patients received } \\
\text { antimicrobial prophylaxis, } \\
\text { people who entered the room } \\
\text { were advised to change shoes, } \\
\text { put on mask and cap and } \\
\text { wash hands. A diet with a low } \\
\text { microbial load was permitted. }\end{array}$ & $\begin{array}{l}95 \% \text { of patients presented } \\
\text { fever and, in } 50 \% \text {, no } \\
\text { infection was diagnosed. } \\
\text { In most positive blood } \\
\text { cultures, pathogens from } \\
\text { endogenous flora were found. } \\
\text { One patient }(2.5 \%) \text { with } \\
\text { probable pre-transplantation } \\
\text { fungal pneumonia died on } \\
\text { D+66. After D+100, eight } \\
\text { deaths occurred and, in } \\
\text { one case, aspergillosis and } \\
\text { disseminated tuberculosis } \\
\text { were the probable cause of } \\
\text { death. }\end{array}$ & $\begin{array}{l}\text { Low initial mortality } \\
\text { and absence of severe } \\
\text { infections suggest that } \\
\text { allogeneic HSCT can } \\
\text { be performed in rooms } \\
\text { without a HEPA filter. } \\
\text { Antimicrobials would be } \\
\text { used more selectively if } \\
\text { the filter were present. }\end{array}$ \\
\hline
\end{tabular}


(continuation)

\begin{tabular}{|c|c|c|c|c|c|}
\hline Study & Category & $\begin{array}{l}\text { Design/ } \\
\text { Sample }\end{array}$ & $\begin{array}{c}\text { Aim/ } \\
\text { Intervention }\end{array}$ & Main results & $\begin{array}{c}\text { Conclusion/ } \\
\text { Recommendation }\end{array}$ \\
\hline $\begin{array}{l}\text { Tejada et } \\
\text { al. }{ }^{(28)}\end{array}$ & $\begin{array}{l}\text { Protective } \\
\text { isolation }\end{array}$ & $\begin{array}{l}\text { Descriptive } \\
09 \text { children } \\
\text { submitted to } \\
\text { autologous and } \\
22 \text { to allogeneic } \\
\text { transplantation. }\end{array}$ & $\begin{array}{l}\text { Assess the incidence of } \\
\text { infection. Individual rooms, } \\
\text { reverse isolation, barrier } \\
\text { measures, air filters (for } \\
\text { gross particles), sterile } \\
\text { diet, decontamination of } \\
\text { gastrointestinal tract and } \\
\text { degerming solution for bathing } \\
\text { were used. }\end{array}$ & $\begin{array}{l}73 \% \text { of patients were used. } \\
\text { Five displayed inflammatory } \\
\text { signs related to the central } \\
\text { catheter. Microorganisms } \\
\text { were isolated in } 12 \text { allogeneic } \\
\text { receptors, } 07 \text { of which were } \\
\text { bacteremia caused by S. } \\
\text { epidermidis. }\end{array}$ & $\begin{array}{l}\text { Reverse isolation with } \\
\text { a simple barrier permits } \\
\text { transplantation in safe } \\
\text { conditions, without } \\
\text { the need for more } \\
\text { sophisticated equipment. }\end{array}$ \\
\hline $\begin{array}{l}\text { Russell et } \\
\text { al. }^{(29)}\end{array}$ & $\begin{array}{l}\text { Protective } \\
\text { isolation }\end{array}$ & $\begin{array}{l}\text { Descriptive } \\
50 \text { adult patients } \\
\text { submitted to } \\
\text { allogeneic HSCT. }\end{array}$ & $\begin{array}{l}\text { Check the benefits of protective } \\
\text { isolation to prevent infections } \\
\text { in HSCT. Individual rooms were } \\
\text { used and isolation measures } \\
\text { were abolished. Patients could } \\
\text { leave the hospital, a diet with a } \\
\text { low microbial load was offered, } \\
\text { antimicrobial prophylaxis, } \\
\text { without any orientation as } \\
\text { to changes in the home } \\
\text { environment. }\end{array}$ & $\begin{array}{l}\text { No cases of bacteremia by } \\
\text { gram-negative or fungal } \\
\text { infections occurred, } 82 \% \text { of } \\
\text { patients presented fever, and } \\
\text { pneumonia was diagnosed in } \\
\text { three cases. In } 22 \% \text { of blood } \\
\text { cultures, S. epidermidis grew. } \\
\text { The } 20 \text { patients who lived } \\
\text { in the city where the HSCT } \\
\text { center was located could } \\
\text { go home, generally at night, } \\
\text { on average for eight days, } \\
\text { and three spend } 90 \% \text { of } \\
\text { the time outside the unit. Of } \\
\text { the } 20 \text { patients, seven were } \\
\text { discharged before the graft. }\end{array}$ & $\begin{array}{l}\text { HSCT can be performed } \\
\text { safely without the use } \\
\text { of protective isolation or } \\
\text { patients' confinement } \\
\text { inside the hospital. }\end{array}$ \\
\hline $\begin{array}{l}\text { Dekker et } \\
\text { al. }{ }^{(30)}\end{array}$ & $\begin{array}{l}\text { Protective } \\
\text { isolation }\end{array}$ & $\begin{array}{l}\text { Descriptive } \\
\text { Patients older } \\
\text { than } 16 \text { years } \\
\text { submitted to } \\
\text { autologous HSCT, } \\
59 \text { with and } 54 \\
\text { without protective } \\
\text { isolation. }\end{array}$ & $\begin{array}{l}\text { Assess results of antimicrobial } \\
\text { prophylaxis in patient groups } \\
\text { with or without protective } \\
\text { isolation. This involved } \\
\text { individual rooms, use of } \\
\text { mask, cap, gown, gloves and } \\
\text { foot protectors, diet with low } \\
\text { microbial load and sterilized } \\
\text { objects. }\end{array}$ & $\begin{array}{l}\text { HSCT with isolation: } 25 \\
\text { infections were diagnosed, } \\
\text { two patients died of } \\
\text { aspergillosis and candidiasis. } \\
\text { HSCT without isolation: } 19 \\
\text { infections were diagnosed, } \\
\text { two died of infection } \\
\text { (Acinetobacter isolate in one } \\
\text { case and pneumonia in the } \\
\text { other, without identifying the } \\
\text { causal agent). }\end{array}$ & $\begin{array}{l}\text { Isolation is not } \\
\text { recommended as no } \\
\text { benefits were found } \\
\text { related to its use. }\end{array}$ \\
\hline $\begin{array}{l}\text { Russel et } \\
\text { al. }{ }^{(31)}\end{array}$ & $\begin{array}{l}\text { Protective } \\
\text { isolation }\end{array}$ & $\begin{array}{l}\text { Descriptive } \\
288 \text { patients } \\
\text { submitted to } \\
\text { allogeneic HSCT. }\end{array}$ & $\begin{array}{l}\text { Assess infection and mortality } \\
\text { patterns related to HSCT } \\
\text { during the first } 100 \text { days post- } \\
\text { transplantation. HSCT were } \\
\text { performed in individual rooms, } \\
\text { patients could freely leave the } \\
\text { room and the hospital, received } \\
\text { antimicrobial prophylaxis, diet } \\
\text { with low antimicrobial load, and } \\
\text { no orientations on changes at } \\
\text { home. }\end{array}$ & $\begin{array}{l}\text { During the first } 28 \text { days, } \\
57 \% \text { of patients had a fever, } \\
30 \text { presented clinical or } \\
\text { radiological foci, besides } \\
\text { positive cultures. In } 25 \% \text { of } \\
\text { collected urine cultures, S. } \\
\text { epidermidis was found and, } \\
\text { in } 25 \%, \mathrm{C} \text {. albicans. Four out } \\
\text { of } 38 \text { deaths during the first } \\
100 \text { days were caused by } \\
\text { Aspergillus species. } 25 \% \text { of } \\
\text { hospitalization days occurred } \\
\text { outside the unit. }\end{array}$ & $\begin{array}{l}\text { Protective isolation is } \\
\text { not recommended and } \\
\text { a HEPA filter should be } \\
\text { used in case of airborne } \\
\text { infections at the HSCT } \\
\text { unit. }\end{array}$ \\
\hline $\begin{array}{l}\text { Mank, } \\
\text { Lelie }^{(32)}\end{array}$ & $\begin{array}{l}\text { Protective } \\
\text { isolation } \\
\text { Masks }\end{array}$ & $\begin{array}{l}\text { Systematic review } \\
\text { Survey: } 101 \\
\text { European } \\
\text { hospitals } \\
\text { Monitoring: } 81 \\
\text { acute leukemia } \\
\text { and } 97 \text { HSCT } \\
\text { patients. }\end{array}$ & $\begin{array}{l}\text { This study was a systematic } \\
\text { literature review on the use of } \\
\text { protective isolation, a survey on } \\
\text { infection prevention practices, } \\
\text { assessment of potential } \\
\text { infection sources at an HSCT } \\
\text { unit, and a monitoring study on } \\
\text { infection incidence before and } \\
\text { after protective isolation had } \\
\text { been banished. }\end{array}$ & $\begin{array}{l}\text { In the review, no difference } \\
\text { in infection incidence } \\
\text { levels was found between } \\
\text { patients in isolation or not. } \\
\text { In the survey, differences } \\
\text { were observed among the } \\
\text { centers regarding the use of } \\
\text { masks, gloves, gowns and } \\
\text { alcohol for hand cleaning. } \\
\text { Professionals' hands } \\
\text { represented an important } \\
\text { source of microorganisms. } \\
\text { The monitoring study showed } \\
\text { similar infection rates in both } \\
\text { groups. }\end{array}$ & $\begin{array}{l}\text { The use of protective } \\
\text { isolation can be } \\
\text { interrupted and adequate } \\
\text { hand hygiene is needed. }\end{array}$ \\
\hline
\end{tabular}

Figure 1 - Synthesis of studies included in the integrative review, Ribeirão Preto, Brazil, 2010 


\section{Analysis of data extracted from the papers}

HEPA filters can remove up to $99.97 \%$ of suspended particles with a maximum diameter of $0.3 \mu \mathrm{m}$. Its main function is to prevent airborne fungal infections, especially those caused by Aspergillus species, with mortality rates amounting to $95 \%$. In guidelines published on opportunistic infection prevention among HSCT receivers ${ }^{(4-5,33)}$, the use of a protective environment is recommended, aimed at minimizing fungal spore counts in the air and to reduce the risk of environmentrelated invasive fungal infection among allogeneic HSCT receivers, with HEPA filters as one item in the protective environment.

As evidenced in the analyzed studies ${ }^{(18,20,22-23)}$, filters are particularly important in sites nearby constructions, as these are an important risk factor for airborne fungal infections. Thus, despite weak evidence levels, the results of the analyzed studies support CDC recommendations for filter use in allogeneic transplantations, especially in case of fungal infection episodes and during constructions or activities that produce dust at the transplantation unit or nearby ${ }^{(4-5)}$. Data presented in an evidence level I study also support recommendations regarding filter use ${ }^{(26)}$. Only one study(27), also descriptive, reported that filters would not be needed, although the authors remained cautious, as the sample was limited and other measures, such as antifungal agents, were used against the possibility of this infection type.

Regarding autologous transplantations, although some studies report that using filters would be prudent in this population ${ }^{(20-21,23,25)}$, further research is needed The evidence level I study included in the sample rejected this indication ${ }^{(26)}$

According to CDC guidelines(4), although the need to use HEPA filters for autologous transplantation receivers had not been established yet at the time the guideline was published, it was already reported that its use should be assessed for these patients in case of prolonged neutropenia. As recommendations refer to allogeneic HSCT, each unit's conditions, characteristics and reality need to be assessed for decision making on filter use for autologous receivers.

Positive results on the use of HEPA filters are also evidenced in studies that, after the start of transplantations at a unit with a HEPA filter, observed a reduction in the incidence of aspergillosis(34). Some researchers, however, are cautious to affirm the utility of this equipment as, despite the decrease in fungal infection rates, no reduction in mortality rates was observed(35).
It was observed in the studies that other protective environment measures ${ }^{(5,33)}$ were also used, including positive air pressure between the entry hall and rooms, directed air flow, automatic closing doors, room sealing to prevent air from entering, gasket of ventilation pipes and construction of rigid barriers to impede the entry of dust and Aspergillus spores at the HSCT units.

Regarding protective isolation, the CDC abolished the recommendation for its use in the 1980's. Unti today, however, it has been used and can include different combinations of measures, as evidenced in the analyzed studies.

Although researchers report that protective isolation can be used safely to perform transplantations ${ }^{(27-28)}$, it should be highlighted that this consideration refers to situations in which the HEPA filter is not available and that this recommendation was based on research data with weak evidence levels. Although the results of an evidence level I study indicated that protective isolation was effective(26), it should be taken into account that, in this case, the HEPA filter was considered a protective isolation item.

About protective isolation measures, in one study ${ }^{(26)}$, it is highlighted that the use of barrier measures is very important nowadays due to high resistant pathogen rates inside hospitals. This recommendation, however, is considered in disagreement with CDC recommendations. Hand washing, use of standard precautions and transmission-based precautions, when necessary, are sufficient to prevent cross infections when adequately used $^{(4)}$

The results of most analyzed studies are in line with CDC indications. The main reason to abolish the use of this measure is based on the fact that causal agents of infections affecting these patients in the neutropenia phase are mostly microorganisms from endogenous flora, which affect the bloodstream or deep organs due to the rupture of the cutaneous and mucous barriers. In these cases, the use of diets with low antimicrobial loads is suggested, as well as decontamination of the gastrointestinal tract with non-absorbable oral antibiotics and use of antimicrobial prophylaxis.

Furthermore, as highlighted in two descriptive studies $^{(29,31)}$, the possibility of outpatient HSCT needs to be taken into account. In studies that assessed the effects and results of this transplantation mode, it was verified that graft time, fever, days using antibiotics, percentage of positive blood cultures and infections types were similar between groups treated at the hospital or in an outpatient scheme. These data indicate that this 
type of program is safe, increases patients and families' quality of life and maximizes the use of hospital beds and resources ${ }^{(36)}$.

Other researchers did not manage to identify significant differences in infection or mortality rates either, between patients kept in protective isolation and patients who were not isolated(37). Hence, it is recommended that, when possible, HSCT receivers be placed in individual rooms ${ }^{(33)}$, without the need for barrier measures.

Regarding patients, professionals or visitors' use of masks, only two surveys were identified in which the use of this equipment at the transplantation units was reported on as a measure to prevent airborne infections ${ }^{(25,32)}$. These results cannot sustain recommendations for their use.

According to current guidelines(5), professionals should use surgical masks as individual protection equipment. Their use is not indicated as an infection transmission prevention measure. To reduce the transmission of airborne pathogens, people with upper airway infection symptoms need to be screened in order to avoid contact with HSCT receivers, and need to be dismissed from care delivery to patients. Also, professionals need to be vaccinated ${ }^{(4)}$.

Although masks are used as part of infection control programs caused by respiratory viruses, with positive results(38), these derive from a set of measures and should not be exclusively attributed to mask use.

Current guidelines(5) indicate that any patient should use simple masks in case of coughing to limit the potential dissemination of infected respiratory secretions. Special respirators (N95 or FFP2 masks), used to prevent small particle inhalation, are indicated for use by HSCT patients during the neutropenia phase, if they manage to tolerate this equipment, to avoid exposure to fungi during transportation near construction or renovation areas. There are no recommendations as to their use when leaving the unit if there are no construction areas nearby ${ }^{(5,33,39)}$.

Considering the possible consequences of infectious processes for HSCT receivers, nurses and the health team working in this area need to be prepared for attendance to patients' needs, and their practice needs to be based on scientific knowledge to support the implementation of confirmed effective measures. In this process, changes in HSCT need to be taken into account, such as the appearance of new antimicrobial agents, the use of less intense conditioning regimens, the increased age of HSCT receivers and the more frequent use of alternative stem cell donors; characteristics that can influence infection types and incidence rates.

\section{Conclusion and final considerations}

With a view to infection prevention in patients submitted to HSCT, this study provided support for decision making on the use of HEPA filters, protective isolation and masks by patients, health professionals and visitors, permitted improved nursing care delivery to these clients.

According to one evidence level I study, one moderate evidence level study and seven classified as weak evidence, HEPA filters should be used for allogeneic HSCT, especially in case of fungal infection episodes and during construction works or activities that produce dust at or near the hospitalization unit. As for autologous HSCT, the analyzed studies do not sustain the use of filters. Thus, further research is recommended to verify the need to use a HEPA filter for these patients.

About the use of protective isolation, although the only evidence level I publication indicated better transplantation results when it is used, in that study, the HEPA filter was part of protective isolation. Based on the results and conclusion of six weak-evidence studies, there is no indication to use protective isolation, as it would not be useful to prevent the main infections that affect patients in this phase.

Regarding masks, no studies with strong evidence were found to justify their use for infection prevention among HSCT receivers. Health professionals should use them as individual protective equipment, in accordance with CDC guidelines. CDC recommendations should also be followed related to allogeneic HSCT receivers' use of special respirators.

These study results contribute to nursing care planning for HSCT patients. It is obvious that randomized controlled studies are needed to clarify existing questions and to support decision making on the application of these measures in clinical practice, which will help to improve the quality of care delivery to transplanted patients. In this process, not only nurses, but the entire team and health institutions' efforts are important to achieve better results, greater client and family satisfaction, and also to reduce costs for the institution and patients. 


\section{References}

1. Devine $\mathrm{H}$, Demeyer $\mathrm{E}$. Hematopoietic cell transplantation in the treatment of leukemia. Semin Oncol Nurs. 2003;19(2):118-32.

2. Pasquini R. Fundamentos e biologia do transplante de células hematopoéticas. In: Zago MA, Falcão RP, Pasquini R. Hematologia fundamentos e prática. São Paulo: Atheneu; 2004.

3. Curcioli ACJV, Carvalho EC. Infusion of hematopoietic stem cells: types, characteristics, adverse and transfusion reactions and implications for nursing. Rev. Latino-Am. Enfermagem. 2010;18(4):716-24.

4. Centers for Disease Control and Prevention (CDC). Guidelines for preventing opportunistic infections among hematopoietic stem cell transplant recipients. MMWR Recomm. Rep. 2000;49(RR-10):1-125.

5. Siegel JD, Rhinehart E, Jackson M, Chiarello $L$, the Healthcare Infection Control Practices Advisory Committee. Guideline for Isolation Precautions: Preventing Transmission of Infectious Agents in Healthcare Settings. 2007 [acesso 12 nov 2009] Disponível em: ww.cdc.gov/ncidod/dhqp/pdf/guidelines/ isolation2007.pdf

6. Secretaria de Estado da Saúde (SP). Informes técnicos. São Paulo; 28 nov 1991;3(15):1-12.

7. Garner JS. and The Hospital Infection Control Practices Advisory Committee. Guidelines for isolation precautions in hospitals. Infect Control Hosp Epidemiol. 1996;17(4):53-80.

8. Galvão CM, Sawada NO, Mendes IAC. A busca das melhores evidências. Rev EsC Enferm USP. 2003;37(4):43-50.

9. Whittemore $\mathrm{R}$, Knafl $\mathrm{K}$. The integrative review: updated methodology. J Adv Nurs. 2005;52(5):546-53. 10. Stetler CB, Morsi D, Rucki S, Broughton S, Corrigan B, Fitzgerald $\mathrm{J}$, et al. Utilization-focused integrative reviews in a nursing service. Appl Nurs Res. 1998;11(4):195-206.

11. Ganong LH. Integrative reviews or nursing research. Res Nurs Health. 1987;10(1):1-11.

12. Beyea SC, Nicoll LH. Writing an integrative review. AORN J. 1998;67(4):877-80.

13. Broome ME. Integrative literature reviews for the development of concepts. In: Rodgers BL, Knafl KA. Concept development in nursing: foundations, techniques and applications. Philadelphia: WB Saunders; 2000. p. 231-50.
14. Santos, CMC, Pimenta CAM, Nobre MRC. A estratégia PICO para a construção da pergunta de pesquisa e busca de evidências. Rev. Latino-Am. Enfermagem. 2007;15(3):508-11.

15. Pellizzon RF. Pesquisa na area da saúde: 1. Base de dados DECs (Descritores em Ciências da Saúde). Acta Cir Bras. 2004;19(2):153-63.

16. Melnyk BM, Fineout-Overholt E. Making the case for evidence-based practice. In: Melnyk BM, Fineout-Overholt E. Evidence-based practice in nursing \& healthcare. A guide to best practice. 2nd ed. Philadelphia: Lippincot Williams \& Wilkins; 2011. p. 3-24.

17. Vasques CI, Rodrigues CC, Reis PED, Carvalho, EC. Nursing care for hodgkin's lymphoma patients subject to chemotherapy: an integrative review. Online Braz J Nurs. [internet]. 2008 [acesso 28 mai 2010]; 7(1). Disponível em: http://www.objnursing.uff.br//index. php/nursing/article/view/1416

18. Barnes RA, Rogers TR. Control of an outbreak of nosocomial aspergillosis by laminar air-flow isolation. J Hosp Infect. 1989;14(2):89-94.

19. Johnson E, Gilmore M, Newman J, Stephens M. Preventing fungal infections in immunocompromised patients. Br J Nurs. 2000;9(17):1154-64

20. Oren I, Haddad N, Finkelstein R, Rowe JM. Invasive pulmonary aspergillosis in neutropenic patients during hospital construction: before and after chemoprophylaxis and institution of HEPA filters. Am J Hematol. 2001;66(4):257-62.

21. Hahn T, Cummings $M$, Michalek AM, Lipman BJ, Segal BH, McCarthy JR PL. Efficacy of high-efficiency particulate air filtration in preventing aspergillosis in immunocompromised patients with hematologic malignancies. Infect Control Hosp Epidemiol. 2002;23(9):525-31.

22. Krüger $W H$, Zöllner $B$, Kaulfers $P M$, Zander AR. Effective protection of allogeneic stem cell recipients against aspergillosis by HEPA air filtration during a period of construction - a prospective survey. J Hematother Stem Cell Res. 2003;12(3):301-7.

23. Nihtinen A, Anttila VJ, Richardson M, Meri T, Volin $L$, Ruutu T. The utility of intensified environmental surveillance for pathogenic moulds in a stem cell transplantation ward during construction work to monitor the efficacy of HEPA filtration. Bone Marrow Transplant. 2007;40(5):457-60. 
24. Passweg JR, Rowlings PA, Atkinson KA, Barrett AJ, Gale RP, Gratwohl A, et al. Influence of protective isolation on outcome of allogeneic bone marrow transplantation for leukemia. Bone Marrow Transplant. 1998;21:1231-8.

25. Krüger $W H$, Hornung RJ, Hertenstein $B$, Kern WV, Kröger N, Ljungman $\mathrm{P}$, et al. Practices of infectious disease prevention and management during hematopoietic stem cell transplantation: a survey from the European group for blood and marrow transplantation. european group for blood and marrow transplantation. J Hematother Stem Cell Res. 2001;10(6):895-903.

26. Schlesinger A, Paul M, Gafter-Gvili A, Rubinovitc B, Leibovici $L$. Infection-control interventions for cancer patients after chemotherapy: a systematic review and meta-analysis. Lancet Infect Dis. 2009;9(2):97-107.

27. Kumar R, Naithani R, Mishra P, Mahapatra M, Seth T, Dolai TK, et al. Allogeneic hematopoietic SCT performed in non-HEPA filter rooms: initial experience from a single center in India. Bone Marrow Transplant. 2009;43(2):15-9.

28. Tejada EO, Regalado MSM, Villa AM, Oteya JP, Laraña JG. Trasplante de médula ósea en enfermedades malignas en la edad pediátrica con aislamiento inverso convencional: valoración de resultados. An Esp Pediatr. $1992 ; 36(6): 433-6$.

29. Russell JA, Poon MC, Jones AR, Woodman RC, Ruether BA. Allogeneic bone-marrow transplantation without protective isolation in adults with malignant disease. Lancet. 1992;339(8784):38-40.

30. Dekker AW, Verdonck LF, Rozenberg-Arska M. Infection prevention in autologous bone marrow transplantation and the role of protective isolation. Bone Marrow Transplant. 1994;14(1):89-93.

31. Russell JA, Chaudhry A, Booth K, Brown C, Woodman $\mathrm{RC}$, Valentine $\mathrm{K}$, et al. Early outcomes after allogeneic stem cell transplantation for leukemia and myelodysplasia without protective isolation: a 10-year experience. Biol Blood Marrow Transplant. 2000;6(2):109-14.

32. Mank A, Van Der Lelie $H$. Is there still an indication for nursing patients with prolonged neutropenia in protective isolation? An evidence-based nursing and medical study of 4 years experience for nursing patients with neutropenia without isolation. Eur J Oncol Nurs. 2003;7(1):17-23.
33. Yokoe D, Casper C, Dubberke E, Lee G, Munõz $\mathrm{P}$, Palmore $\mathrm{T}$, et al. Infection prevention and control in health-care facilities in which hematopoietic cell transplant recipients are treated. Bone Marrow Transplant. 2009;44(8):495-507.

34. Maehara $Y$, Nagasaki $Y$, Kadowaki M, Eriguchi $Y$, Miyake N, Uchida $Y$, et al. Hematological unit invasive aspergillosis epidemiology. Kansensshogaku Zasshi. 2010;84(2):176-81.

35. Eckmanns T, Rüden $H$, Gastmeier P. The influence of high-efficiency particulate air filtration on mortality and fungal infection among highly immnunosuppressed patients: a systematic review. J Infect Dis. 2006;193(10): 1408-18.

36. McDiarmid S, Hutton B, Atkins H, Bence-Bruckler I, Bredeson C, Sabri E, et al. Performing allogeneic and autologous hematopoietic SCT in the outpatient setting: effects on infectious complications and early transplant outcomes. Bone Marrow Transplant. In press 2009. [acesso 28 mai 2010]; Disponível em: http:// www.nature.com/bmt/journal/vaop/ncurrent/pdf/ bmt2009330a.pdf

37. Zitella LJ, Friese CR, Hauser J, Gobel BH, Woolery M, $\mathrm{O}$ 'Leary $\mathrm{C}$, et al. Putting evidence into practice: prevention of infection. Clin J Oncol Nurs. 2006;10(6):739-50.

38. Lavergne V, Ghannoum M, Weiss K, Roy J, Béliveau C. Successful prevention of respiratory syncytial virus nosocomial transmission following an enhanced seasonal infection control program. Bone Marrow Transplant. In press 2010. Disponível em: http://www.nature.com/ bmt/journal/vaop/ncurrent/pdf/bmt201067a.pdf

39. Raad I, Hanna H, Osting C, Hachem R, Umphrey J, Tarrand J, et al. Masking of neutropenic patients on transport from hospital rooms is associated with a decrease in nosocomial aspergillosis during construction. Infect Control Hosp Epidemiol. 2002;23(1):41-3.
Received: June $6^{\text {th }} 2010$ Accepted: Mar. $3^{\text {rd }} 2011$ 